\title{
An Analysis of the Factors Influencing the Value Promotion of Chinese E-Commerce Enterprises Based on Amos Model
}

\author{
Li-Hua Xia
}

\begin{abstract}
Based on the data of 148 e-commerce enterprises in China, Amos in the structural equation model is used as the analysis tool to build the verification model of e-commerce enterprise value promotion. 12 observation variables, such as the proportion of $R \& D$ expenditure to sales revenue and the proportion of $\mathbf{R} \& \mathbf{D}$ expenditure to sales revenue, are selected to explore innovation competitiveness, scale competitiveness, risk competitiveness and business competitiveness. The difference of competitive power has an impact on the promotion of enterprise value. This paper puts forward the suggestions of strengthening supply chain cost control, diversification strategy and cooperation and sharing, which is of practical significance to improve the core value of e-commerce enterprises.
\end{abstract}

Index Terms-AMOS model, e-commerce enterprises, value promotion.

\section{INTRODUCTION}

With smart phones as the interface, the world has entered the era of big data. Big data not only changes people's lifestyle, but also changes the development mode of enterprises. Under the severe impact of the electric business enterprises, enterprises relying solely on offline sales have been unable to maintain normal operation, and have turned to the development mode of OTO integration. Since 2017, China's electricity supplier industry has been developing steadily. Domestic policies have further fallen into the transformation effect of "Internet +" strategy in all walks of life, and supply side structural reform and consumption upgrading have played a supporting role in promoting the steady development of the electricity supplier mode. The e-commerce industry has entered the rational adjustment period from the extensive and rapid development stage. Enterprises pay more attention to fine operation and regional development, and gradually improve their service capacity in the whole industry chain. At the end of 2018, the Ministry of Industry and Information Technology issued a $5 \mathrm{G}$ system test frequency license, and the Political Bureau of the CPC Central Committee issued top-level plans and designs for the development and utilization of the new generation of artificial intelligence in China. E-commerce enterprises will play a more powerful role in the economy. The industry will play an increasingly important role in the capital market. Enterprises will accelerate the development of the Internet of Things, logistics, electronic payment and distribution of supply chain finance. In order to improve the overall profitability of e-commerce enterprises, it is necessary to

Manuscript received April 17, 2020; revised July 4, 2020.

Lihua Xia is with Taizhou University, China (e-mail: 261488796@qq.com). manage and control the various elements in order to create greater value. In the face of such a development trend, how e-commerce enterprises can develop and grow in the increasingly fierce competition, and how to achieve value enhancement in the industry has become a very urgent issue.

Shuan Liu (2010) pointed out that analytic hierarchy process (AHP), Balanced Scorecard (BSC) and data envelopment analysis (DEA) are often used to evaluate the performance of e-commerce enterprises. The difficulties encountered in the performance evaluation of e-commerce enterprises are mainly manifested in the data analysis method, and other losses will offset the profits obtained by e-commerce enterprises [1]. Caihua Liu et al. (2012) used the Balanced Scorecard to design a set of performance evaluation index system for e-commerce enterprises, including financial indicators, market share, customer retention rate and other non-financial indicators, and constructed an analytic hierarchy process model to evaluate the performance of e-commerce enterprises [2]. Linqi Wang (2014) believes that the core values of e-commerce enterprises include eight aspects: network operation mode, marketing solutions to meet customer needs, building their own brand, commodity types, website technology, logistics and distribution, striving to build an information platform, and improving service level [3]. The above-mentioned evaluation of e-commerce enterprise value is mostly based on future cash flow discount model or user contribution model. However, the factors such as R\& D innovation, risk competition and profit model have not been paid attention to, which is more suitable for the development of mature e-commerce enterprises, but there is no stable revenue and profit in the initial and growth stages [4]. Cash flow enterprises are not adapted. According to the particularity of e-commerce enterprises and the influencing factors of enterprise value, a new value evaluation and analysis model is constructed.

\section{STUdy MethoD}

\section{A. The Basic Principle of Structural Equation Modeling}

Structural equation model (SEM for short) originated from path analysis and factor analysis. It is a method of establishing and testing causality model. In 1970s, Keesing (1972) and Wiley (1973) Joreskog (1973) integrated factor analysis technology into path analysis, and put forward a general model that marked the emergence of structural equation model [5]. It can be used to analyze the effect of individual indicators on the whole and the relationship between individual indicators, instead of multiple regression and covariance analysis. The advantage of structural equation 
analysis over traditional analysis is that it can deal with multiple dependent variables at the same time. It can test whether the relationship between variables has changed and whether the mean difference of each factor is significant.

\section{B. Construction of Structural Equation Modeling}

There are two basic models in the equation model: measurement model and structural model. The measurement model consists of manifest indicators and latent variables, and is a linear function of observation variables. Manifest indicators, also known as observation variables, refer to the variables that can be measured by a specific method to obtain specific values. Latent variables, as opposed to explicit variables, cannot be measured or observed to obtain specific values, which need to be reflected by measured indicators. Structural model is a combination of factor analysis and path analysis. It mainly studies the relationship between manifest indicators and latent variables, as well as the relationship between latent variable [6]. In the SEM analysis model, the regression relationship of the measurement model is confirmatory factor analysis, which explores the causal relationship between latent variable and observation variables. The regression relationship of the structural model is equivalent to the traditional path analysis, which directly explores the causal relationship between latent variable.

The regression equation of the measurement model is as follows:

$$
\begin{aligned}
& \mathrm{Xn}=\lambda \mathrm{n} \zeta \mathrm{n}+\delta \mathrm{n} \\
& \mathrm{Yn}=\lambda \mathrm{n} \eta \mathrm{n}+\varepsilon \mathrm{n}
\end{aligned}
$$

The regression equation can be expressed by matrix equation as follows:

$$
\begin{aligned}
& \mathrm{X}=\Lambda \mathrm{x} \zeta+\delta \\
& \mathrm{Y}=\Lambda \mathrm{y} \eta+\varepsilon
\end{aligned}
$$

where $\zeta$ is not correlated with $\delta, \eta$ and $\varepsilon$, and vice versa. $\Lambda \mathrm{x}$ and $\Lambda \mathrm{y}$ as indicator variables $(\mathrm{X} \cdot \mathrm{Y})$, the factors of load, the delta, $\delta$ and $\varepsilon$ measurement error of observation variable, $\zeta$ is manifest indicators, $\eta$ is inside Latent variables. In the SEM measurement model, it is assumed that there can be no covariation or causal path between latent variable and measurement errors.

At present, the software that can deal with SEM includes AMOS, LISREL, EQS, Mplus, R. Amos (Analysis of Moment Structures) moment structure analysis, combined with linear model and common analysis technology, has similar structure analysis connotation as covariance matrix, estimates the initial model diagram, verifies the adaptation effect, and outputs the optimal adaptation model after modifying according to the revised index [7].

\section{The CONSTRUCTION AND EMPIRICAL TEST ANALYSIS OF THE VAlue Evaluation MODEl OF E-COMMERCE ENTERPRISES}

\section{A. Sample and Variable Selection}

Referring to the industry classification guidelines, this paper selected the 2018 data of six typical types of Listed Companies in the e-commerce industry of Shanghai and
Shenzhen Stock Exchanges as samples, including 16 e-commerce companies, 25 interconnected finance companies, 32 e-payment companies, 75 Internet of Things companies, and 148 companies which removed the cross-duplication of business and were processed by ST. The data in this paper are collected from the research databases of Cathay Guotaian and RESSET series database. In order to better evaluate the company's value, we preliminarily select indicators and conduct exploratory factor analysis on the data, as shown in Table I.

TABLE I: TEST OF KMO AND BARTLETT

\begin{tabular}{|ll|r|}
\hline K-M-O metric & & .782 \\
Bartlett Sphericity test & Approximate chi square & 674.093 \\
& df & 66 \\
& Sig. & .000 \\
\hline
\end{tabular}

The degree of sphericity $\mathrm{P}$ value is significantly less than 0.05 , and the KMO value is 0.782 . The correlation coefficients between variables and unit arrays are significantly different, which is suitable for factor analysis. Choose orthogonal rotation, according to the result of cumulative explanatory rate of factor variance, extract the cumulative value of square sum loading $79.35 \%$, extract most information of the three principal components which can cover the original variables, select their components as exogenous latent variables, named innovation competitiveness, scale competitiveness, risk competitiveness and operational competitiveness respectively. The

\begin{tabular}{|c|c|c|c|}
\hline dimension & $\begin{array}{l}\text { Variable } \\
\text { Name }\end{array}$ & $\begin{array}{l}\text { Variable } \\
\text { Symbol }\end{array}$ & Variable Interpretation \\
\hline Industry status & $\begin{array}{l}\text { enterprise } \\
\text { value }\end{array}$ & Val & $\begin{array}{l}\text { Per share price } * \text { total } \\
\text { number of shares }\end{array}$ \\
\hline \multirow[t]{3}{*}{$\begin{array}{l}\text { Innovative } \\
\text { Competitiveness }\end{array}$} & $\begin{array}{l}\text { Total } \mathrm{R} \& \mathrm{D} \\
\text { investment }\end{array}$ & TRDi & $\begin{array}{l}\text { Total annual R\&D } \\
\text { expenditure }\end{array}$ \\
\hline & $\begin{array}{l}\text { Proportion } \\
\text { of R\&D } \\
\text { personnel }\end{array}$ & PoRDp & $\begin{array}{l}\text { R\&D personnel/total } \\
\text { enterprise personnel }\end{array}$ \\
\hline & $\begin{array}{l}\text { R\&D as a } \\
\text { percentage } \\
\text { of perating } \\
\text { income }\end{array}$ & RDpoi & $\begin{array}{l}\mathrm{R} \& \mathrm{D} \\
\text { expenditure/operating } \\
\text { income }\end{array}$ \\
\hline \multirow[t]{2}{*}{$\begin{array}{l}\text { Scale } \\
\text { Competitiveness }\end{array}$} & $\begin{array}{l}\text { Operating } \\
\text { income }\end{array}$ & Opin & $\begin{array}{l}\text { Total annual operating } \\
\text { income }\end{array}$ \\
\hline & Total assets & $\mathrm{Ta}$ & $\begin{array}{l}\text { Total assets for the } \\
\text { whole year }\end{array}$ \\
\hline \multirow[t]{3}{*}{$\begin{array}{l}\text { Risk } \\
\text { Competitiveness }\end{array}$} & $\begin{array}{l}\text { Asset-liabil } \\
\text { ity ratio }\end{array}$ & Alr & $\begin{array}{l}\text { Total liabilities/total } \\
\text { assets }\end{array}$ \\
\hline & $\begin{array}{l}\text { Current } \\
\text { ratio }\end{array}$ & $\mathrm{Cr}$ & $\begin{array}{l}\text { Current assets/current } \\
\text { liabilities }\end{array}$ \\
\hline & $\begin{array}{l}\text { Net } \\
\text { operating } \\
\text { cash flow } \\
\end{array}$ & Ncf & $\begin{array}{l}\text { Operational Cash } \\
\text { Flow-Operational Cash } \\
\text { Flow }\end{array}$ \\
\hline \multirow[t]{4}{*}{$\begin{array}{l}\text { Operational } \\
\text { Competitiveness }\end{array}$} & $\begin{array}{l}\text { Return on } \\
\text { net assets }\end{array}$ & Rona & $\begin{array}{l}\text { Net profit/average net } \\
\text { assets }\end{array}$ \\
\hline & $\begin{array}{l}\text { Growth rate } \\
\text { of income }\end{array}$ & Groi & $\begin{array}{l}\text { Increase in Operating } \\
\text { Revenue/Current } \\
\text { Operating Revenue }\end{array}$ \\
\hline & $\begin{array}{l}\text { Earnings } \\
\text { per share }\end{array}$ & Eps & $\begin{array}{l}\text { Net profit/total number } \\
\text { of shares issued }\end{array}$ \\
\hline & $\begin{array}{l}\text { Total asset } \\
\text { turnover }\end{array}$ & Tat & $\begin{array}{l}\text { Operating } \\
\text { Revenue/Average Total } \\
\text { Assets }\end{array}$ \\
\hline
\end{tabular}
relationship between the latent variables and their corresponding observed variables is shown in Table II.

TABLE II: DEFINITION OF VARIABLES 


\section{B. Construction of Initial Model}

AMOS 24.0 software was used to construct a model for validation analysis and to explore the relationship between latent variables and observed variables. According to the set latent variables and corresponding observation variables, the initial model path map of Internet enterprise value analysis structural equation is constructed, as shown in Fig. 1. Because of the different data dimensions, in SPSS 19.0, the operation command of "Analysis - Description Statistics Description" is executed, and the standardized values are saved as variables to reduce errors. The most commonly used method of SEM estimation is maximum likelihood estimation, which is used to estimate various parameters in the model. Sample data conform to the assumption of multivariate normality.

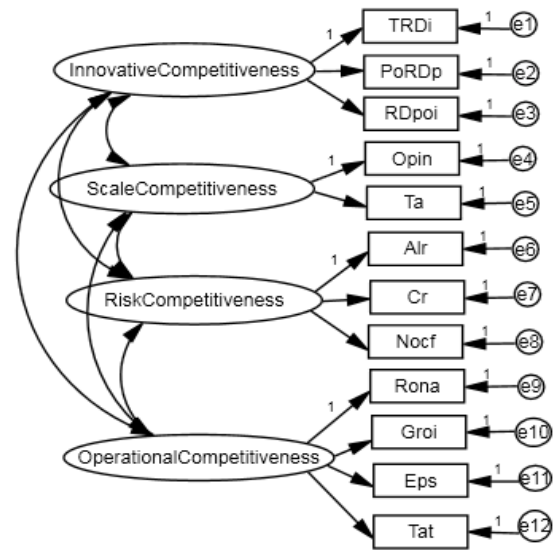

Model Specification

Chi-square $=\mathbf{l}$ min (ldf degree of freedom) $p=\backslash p$

Fig. 1. Structural equation model path map for value analysis of e-commerce enterprises.

The operation calculation is checked, and the standardized output parameters of the model are between 0 and 1 except the reverse index asset-liability ratio, which is in line with the actual operation. But the ratio of absolute fitness index $\mathrm{CMIN} / \mathrm{DF}=7.517$ (normal range is less than 3), mean error square root $\mathrm{RMSEA}=0.18$ (better fit than 0.08), benign fitness index $\mathrm{GFI}=0.719, \mathrm{NFI}=0.684$ (better fit than 0.9 ), $\mathrm{P}$ value is 0.023 , less than 0.05 , rejecting the assumption of initial model setting, need to be revised according to parameter hints [8].

\section{Fitting and Modifying Model}

Table III is the first validation result of the model. At the significant level of $\mathrm{p}=0.05$, only the path coefficients between innovation risk competitiveness and liquidity ratio are not significant, while the path coefficients between other latent variables, observation variables and observation variables are significant.

TABLE III: MODEL ESTIMATION PARAMETER TABLE REGRESSION WEIGHTS: (GROUP NUMBER 1 - DEFAULT MODEL)

\begin{tabular}{|c|c|c|c|c|c|c|}
\hline & & & Estimate & S.E. & C.R. & $\mathrm{P}$ \\
\hline Opin & $\begin{array}{l}<- \\
-\end{array}$ & $\begin{array}{l}\text { Scale } \\
\text { Competitiveness }\end{array}$ & 1.000 & & & \\
\hline $\mathrm{Ta}$ & $\begin{array}{l}<- \\
-\end{array}$ & $\begin{array}{l}\text { Scale } \\
\text { Competitiveness }\end{array}$ & 2.162 & $\begin{array}{l}.51 \\
3\end{array}$ & 4.218 & $* * *$ \\
\hline Alr & & $\begin{array}{l}\text { Risk } \\
\text { Competitiveness }\end{array}$ & 1.000 & & & \\
\hline
\end{tabular}

\begin{tabular}{|c|c|c|c|c|c|c|}
\hline & & & Estimate & S.E. & C.R. & $\mathrm{P}$ \\
\hline $\mathrm{Cr}$ & $\begin{array}{l}<- \\
-\end{array}$ & $\begin{array}{l}\text { Risk } \\
\text { Competitiveness }\end{array}$ & -.035 & $\begin{array}{l}.06 \\
1 \\
\end{array}$ & -.583 & .560 \\
\hline Nocf & $\begin{array}{l}<-- \\
-\end{array}$ & $\begin{array}{l}\text { Risk } \\
\text { Competitiveness }\end{array}$ & -.140 & $\begin{array}{l}.17 \\
0 \\
\end{array}$ & -.821 & .015 \\
\hline Rona & $\begin{array}{l}<- \\
-\end{array}$ & $\begin{array}{l}\text { Operational } \\
\text { Competitiveness }\end{array}$ & 1.000 & & & \\
\hline Groi & $\begin{array}{l}<- \\
-\end{array}$ & $\begin{array}{l}\text { Operational } \\
\text { Competitiveness }\end{array}$ & .335 & $\begin{array}{l}.11 \\
3 \\
\end{array}$ & 2.973 & .003 \\
\hline Eps & $\begin{array}{l}<-- \\
-\end{array}$ & $\begin{array}{l}\text { Operational } \\
\text { Competitiveness }\end{array}$ & 1.103 & $\begin{array}{l}.22 \\
8 \\
\end{array}$ & 4.834 & $* * *$ \\
\hline TRDi & $\begin{array}{l}<- \\
-\end{array}$ & $\begin{array}{l}\text { Innovative } \\
\text { Competitiveness }\end{array}$ & 1.000 & & & \\
\hline $\begin{array}{l}\text { PoRD } \\
\mathrm{p}\end{array}$ & $\begin{array}{l}<- \\
-\end{array}$ & $\begin{array}{l}\text { Innovative } \\
\text { Competitiveness }\end{array}$ & .459 & $\begin{array}{l}.10 \\
9 \\
\end{array}$ & 4.196 & $* * *$ \\
\hline RDpoi & $\begin{array}{l}<- \\
-\end{array}$ & $\begin{array}{l}\text { Innovative } \\
\text { Competitiveness }\end{array}$ & .755 & $\begin{array}{l}.13 \\
4 \\
\end{array}$ & 5.631 & $* * *$ \\
\hline Tat & $\begin{array}{l}<- \\
-\end{array}$ & $\begin{array}{l}\text { Operational } \\
\text { Competitiveness }\end{array}$ & .084 & $\begin{array}{l}.08 \\
0\end{array}$ & 1.050 & .294 \\
\hline
\end{tabular}

Looking at the "Modification Indices" option in the output results, through the covariance correction index table (see Table IV), it can be concluded that e4 and e12 are error variables of the observation variables "operating income" and "total assets turnover ". In the initial model, it is assumed that there is no correlation between them. From the calculation formula, there is a covariant relationship between them, if there is a correlation between them. In this system, if the error term between the observed variables is relaxed from the strictly unrelated assumption, the chi-square value can be reduced by at least 76.458 , and the parameter estimation will be changed by 0.432 . The two variables are connected by double arrows.

TABLE IV: COVARIANCE CORRECTION INDEX TABLE COVARIANCES: (GROUP NUMBER 1 - DEFAULT MODEL)

\begin{tabular}{|c|c|c|c|c|}
\hline & & & M.I. & Par Change \\
\hline & $\langle--\rangle$ & e10 & 19.514 & -.253 \\
\hline e8 & $\langle-->$ & $\mathrm{e} 10$ & 4.460 & .168 \\
\hline e7 & $\langle-->$ & e3 & 4.039 & -.093 \\
\hline e9 & $\langle-->$ & Scale Competitiveness & 4.094 & .093 \\
\hline e6 & $\langle-->$ & Operational Competitiveness & 5.101 & .180 \\
\hline e4 & $\langle-->$ & $\mathrm{e} 10$ & 17.293 & .301 \\
\hline e5 & $\langle-->$ & e12 & 42.578 & -.264 \\
\hline e2 & $\langle-->$ & e8 & 4.903 & -.088 \\
\hline e1 & $\langle-->$ & Innovative Competitiveness & 5.753 & -.081 \\
\hline e4 & $\langle-->$ & $\mathrm{e} 12$ & 76.458 & .432 \\
\hline e1 & $\langle-->$ & e6 & 4.242 & -.097 \\
\hline
\end{tabular}

According to the M.I. index value provided by AMOS, each time a parameter is released, a new path is added to the model. After each modification, the revised index of error variables E1 and e10, E4 and e12, E5 and E12 is higher. Corresponding observation variables show that the total $\mathrm{R} \& \mathrm{D}$ expenditure and income growth rate, business income and total asset turnover rate, total assets and total capital are higher. There is an inevitable relationship between the production turnover rate and the symbiotic relationship. We can relax the error terms of these observation variables in turn, which will significantly improve the fitting effect of the model [9]. Therefore, these pairs of error variables are connected by double arrows in the structural equation path diagram. According to the output results, the overall fitting situation is sorted out, as shown in Table V. 
TABLE V: OVERALL FITTING TABLE

\begin{tabular}{l|lll}
\multicolumn{4}{c}{ TABLE V: OVERALL FITTING TABLE } \\
\hline $\begin{array}{l}\text { Fitting } \\
\text { index }\end{array}$ & $\begin{array}{l}\text { Before model } \\
\text { updating }\end{array}$ & $\begin{array}{l}\text { Modified } \\
\text { model }\end{array}$ & $\begin{array}{l}\text { Standard or critical } \\
\text { value of fitting index }\end{array}$ \\
\hline P & 0.023 & 0.25 & $>0.05$ \\
CHI/DF & 7.517 & 1.168 & $<3$ \\
RMSEA & 0.18 & 0.034 & $<0.08$ (The smaller \\
& & & the index value, the \\
& & & better the fitting is.) \\
GFI & 0.719 & 0.959 & $>0.9$ \\
NFI & 0.684 & 0.942 & $>0.9$ \\
CFI & 0.724 & 0.991 & $>0.9$ \\
\hline
\end{tabular}

From the above table, it can be concluded that after model modification, the fitting index can reach or surpass the fitting standard, reflecting that the fitting between model and data is good. The modified model can fit the sample data and meet the absolute adaptability requirements. The constructed model is in good agreement with the actual situation, and the path analysis results are reliable. The revised model path is shown in Fig. 2.

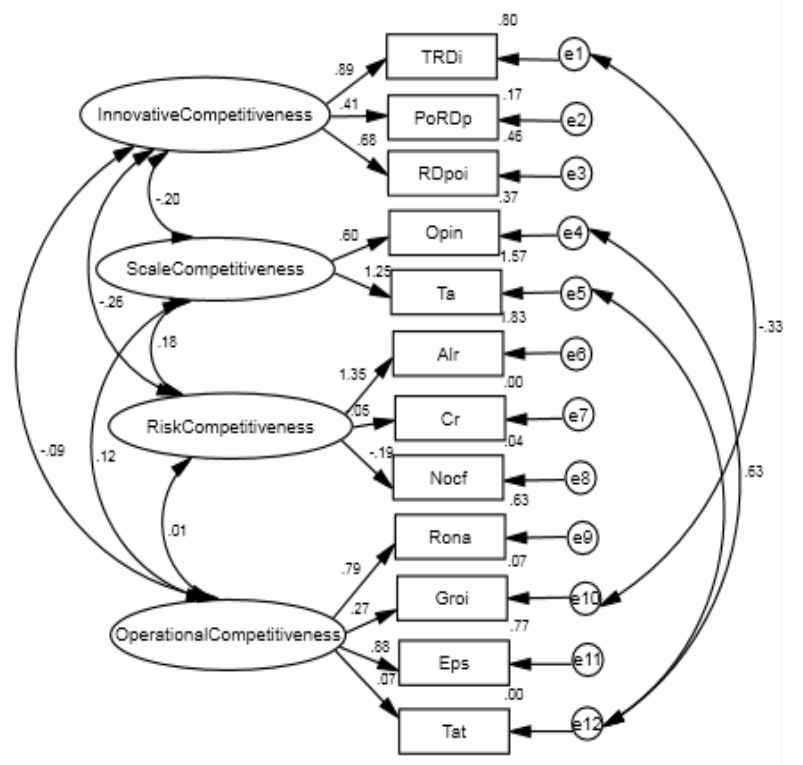

Standardized estimates Chi-square $=\backslash \mathrm{cmin}($ Idf degree of freedom) $p=\mid p$

Fig. 2. Revised structural equation model path map for e-commerce enterprise value analysis.

There are 28 variables in the structural equation model, including 12 observation variables, 16 latent variable, 12 internal variables, 16 external variables (including 4 latent variable plus 12 error variables), and the index variables of the measurement model are observation variables. The number of unique sample moment elements is the number of sample data points, the value is $\mathrm{k}(\mathrm{k}+1) / 2=78$, where $\mathrm{k}$ is the number of observed variables of CFA model. In the model, the chi-square value is 33.547 , and the significance probability value is $p=0.250>0.05$. The null hypothesis is accepted. The hypothesis that the variance covariance $\mathrm{S}$ matrix derived from the observation data is equal to the variance covariance matrix derived from the hypothesis model is supported, i.e. the hypothesis that the model map is suitable for the observation data. In the estimation of measurement model, the parameter of $\lambda$ certain index variable is fixed to 1 between the latent variable and the path coefficient of its observation variable. As to which index variable is fixed, it has no relation. Because after testing with specific data, the value-type maps of standardized estimation of measurement model are the same and the overall fitness statistics are the same.

\section{RESEARCH CONCLUSION}

Empirical research shows that there is a positive causal relationship between endogenous latent variables innovation competitiveness, scale competitiveness, risk competitiveness, operational competitiveness and the path coefficient of core value of e-commerce enterprises. Innovation and scale competitiveness are important factors affecting core competitiveness at the current stage. In contrast, risk competitiveness and operational competitiveness have a weak impact, and companies can give priority to them. Enhance the scale and innovative technology, so as to enhance its value and core competitiveness faster.

The overall effect of R\&D expenditure and total assets on the standardization of core value is at the highest level. Among them, the explanations of total assets on scale competitiveness are stronger, and the explanations of total R\&D expenditure on innovation ability are stronger (the value of $\lambda$ is greater than 0.89 ). Consistent with the current situation that e-commerce enterprises attach importance to $R \& D$ expenditure to enhance core value, the total $R \& D$ expenditure of leading enterprises in the industry and the proportion of $R \& D$ expenditure to business income are increasing year by year; the asset-liability ratio has a strong explanation of risk ability, and the influence of liquidity ratio and net cash flow on risk ability is weak, mainly due to the assets of e-commerce industry. The characteristics are light assets type and high liquidity ratio. Because of the favor of investors, the cash flow of enterprises in the industry is generally higher than that of other industries, which belongs to the industry commonness and cannot constitute a specific factor to explain the value of enterprises. The explanatory power of earnings per share to operational competitiveness is the strongest, and the corresponding explanatory power is close to 0.9 . The explanatory power of return on net assets to operational competitiveness is slightly weaker than that of earnings per share (value of $\lambda$ is close to 0.7 ); The explanatory power of growth rate of operating income and turnover rate of total assets to operational competitiveness is weaker, because many e-commerce enterprises adopt the mode of "burning money" in the initial stage. The growth of business income, especially in the initial stage, has some difficulties, which cannot be well used to explain the improvement of the core competitiveness of enterprises; the turnover rate of total assets is reflected by the ratio between business income and average total assets, while the turnover rate of business income and total assets has well explained the value of enterprises in terms of scale competitiveness instead of total assets turnover rate. If the company data is incomplete or lagged, the observation variables with high explanatory degree can be selected to measure.

Different from traditional industries and general understanding, the impact of operating capacity on the core competitiveness of Listed Companies in China's e-commerce industry is not the most significant. There is no significant correlation between the size of Listed Companies in 
e-commerce industry and their innovation risk ability, innovation and operation ability, scale and operation ability. It shows that there is a lag between the expansion of the company's scale and the profit and capital turnover movement. At the same time, the rapid development of the e-commerce industry, the long profit cycle and the high cash flow characteristics lead to the relationship between profit and risk is not as close as in the traditional industry.

\section{COUNTERMEASURE AND ENLIGHTENMENT}

\section{A. Enhancing Scale Competitiveness}

E-commerce industry follows the law of increasing scale value; network externalities will have a positive impact on the value of enterprises. The effect of increasing scale returns of e-commerce enterprises is more obvious than other industries, because the main products of the Internet industry generally have the characteristics of extensive cost-free replication. With the expansion of the scale, the average cost is decreasing, the revenue is increasing, and the price of enterprises is increasing. Value will be increased, and at the same time, more users will be encouraged to enter, forming a cycle of increasing law. With the continuous development of the Internet, it has brought infiltration among various industries, cross-links of industrial relations and improvement of user stickiness. More and more enterprises are aware of the great value of common user groups among different kinds of websites. This index will promote the integration of e-commerce enterprises and provide a new reference dimension for enterprises to analyze user behavior more accurately. Sharing logistics, data and purchasing channels, in order to reduce the procurement costs and logistics costs of both sides, improve their service quality and level, and then enhance their own development capacity, achieve mutual benefit and win-win. This is in line with the conclusion drawn from the empirical study. Scale competitiveness is an important factor to enhance the value of e-commerce industry [10].

\section{B. Creating a Characteristic Profit Model}

Although most e-commerce enterprises adopt the operation mode of "burning money" when they start up, they still need to consider the distinctive profit points when they start up companies, so as to gain profits as soon as possible and achieve higher value. Through the combination of long-term strategic planning and short-term business plan to adapt to the external environment, enterprises and users will win-win situation. At present, the development direction of many e-commerce platforms is basically determined, but in the way of profit, it has been difficult to balance the relationship between profit and service. With the increase of the scale of e-commerce enterprises, there is only a problem of transaction function in the consumption terminal of e-commerce websites. Faced with an increasingly wide range of groups, the value of users lies in creating profits for enterprises while consuming, while enterprises strive to make users pair with each other. Its products or services produce loyalty and dependence, so we need products with characteristics and service quality should be higher. Only by providing comprehensive and diversified services to enhance the consumer experience of users, can we achieve higher competitiveness. It can make full use of its greater media value to tap its profitability. Secondly, we should realize rational allocation of resources, share logistics system in physical stores, reduce procurement costs, multi-terminal consumption experience and value realization of multi-dimensional user flow, which will greatly reduce procurement costs and further improve the profitability of enterprises.

\section{Continuously Improve the Level of Innovation Technology}

The industry is facing the challenges of diverse, complex and rapid changes in technology and services. New applications, new channels and new business models brought by new technologies such as artificial intelligence, VR, AR and block chain bring new opportunities and challenges for the development of e-commerce industry. In order to adapt to these changes, enterprises should carry out in-depth research and experiments on new technologies and new businesses to continuously improve their technological innovation capabilities. Using big data to strengthen the cost control of supply chain, and using supply chain finance to solve the problem of liquidity turnover in e-commerce trade due to the existence of accounts receivable, inventory or advance payment. China's e-commerce has huge market potential, but there are still large security problems. The funds and information of online transactions can not be guaranteed. Enterprises should strengthen research and development investment in information security. Through external expansion and internal collaboration, we will further optimize and improve the big data industry ecosphere, promote the deep integration of big data, cloud services and artificial intelligence, and focus on exploring a reasonable and efficient mechanism for industrial co-development.

\section{CONFLICT OF INTEREST}

The authors declare no conflict of interest.

\section{AUTHOR CONTRIBUTIONS}

Theoretical research, data analysis and thesis writing are all completed by the author, Lihua Xia.

\section{ACKNOWLEDGMENT}

This paper is a phased research achievement of Taizhou University Professor's Research Fund Project "Construction of Accounting Information Platform for Small and Medium-sized Enterprises Based on Cloud Computing in the Big Data Era" (Project No. QD2016001).

\section{REFERENCES}

[1] S. Liu, "Research on the performance evaluation method of e-commerce enterprises," Modern Economic Information, vol. 22, pp. 89-90, 2010

[2] L. Wang, "Research of the internet enterprise value assessment," Dissertation, Harbin Institute of Technology, 2018.

[3] L. Wang, "B2C e-commerce operation mode and its competitiveness analysis," Logistics Technology, vol. 19, pp. 35-39, 2014.

[4] Y. Wang, "Research on the internet enterprise value evaluation," Economic Research Guide, vol. 31, no. 20, pp. 12-35, 2015.

[5] D. Yi, Structural Equation Model Method and Application, Beijing: Renmin University Press, 2008, pp. 179-235.

[6] M. Wu, Operation and Application of Structural Equation Model-AMOS, Chongqing University Press, pp. 159-246, 2009. 
[7] J. Hou, Z. Wen, and M. Herbert, "Structural equation model testing Cutoff criteria for goodness of fit indices and chi-square test," Acta Psychologica Sinica, vol. 2, pp. 186-194, 2004.

[8] P. Meng, "Earnings quality of Chinese manufacturing listed companies based on structural equation model," Master thesis, Northeast University of Finance and Economics, 2015.

[9] P. M. Benter and C. P. Chou, "Practical issues in structural modeling," Sociological Methods and Research, vol. 16, pp. 78-117, 1987.

[10] J. Guo, "Cost control of supply chain in e-commerce enterprises: A case study of Jingdong Mall," Communication of Finance and Accounting, vol. 32, pp. 68-71, 2017.

Copyright $(\odot 2020$ by the authors. This is an open access article distributed under the Creative Commons Attribution License which permits unrestricted use, distribution, and reproduction in any medium, provided the original work is properly cited (CC BY 4.0).

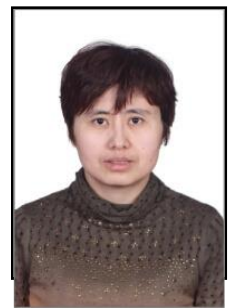

Lihua Xia is a professor in School of Economics an Management, Taizhou University, certified public accountant, financial management discipline leader. She was graduated from Northeast University of Finance and Economics with a master of management, research direction in financial management, accounting computerization. 